\title{
Does More Spending on Education Matter to Human Capital Formation? Study Case of Bengkulu Province, Indonesia
}

\author{
Nurfitriani \\ Department of Economics, Faculty of Economics and Business, \\ Universitas Muhammadiyah Yogyakarta \\ nurfitri979@gmail.com \\ Romi Bhakti Hartarto \\ Department of Economics, Faculty of Economics and Business, \\ Universitas Muhammadiyah Yogyakarta \\ romi.hartarto@gmail.com
}

\begin{abstract}
Based on Statistics Indonesia (BPS), Indonesia will face a demographic bonus era during 20202035. That implies that the number of productive-age population will be higher than elderly people and children (dependents). This phenomenon offers an opportunity due to a lower dependency burden. However, the situation could be catastrophic if the government is not ready to equip the productive age population with necessary skills. The objective of this study is to determine whether or not higher spending on education has positive influence on human capital formation in Bengkulu Province. The research used panel data analysis of ten regions in Bengkulu Province for the 20102014 periods. Research results showed that spending on education does not have significant impact on human capital development, while women empowerment and infrastructure have positive effect on human capital. Our results imply that more spending on education does not matter if it is not supported by quality infrastructure that makes education facilities accessible.
\end{abstract}

Keywords: human capital, HDI, health, education, infrastructure. 


\section{INTRODUCTION}

Changing age structure in a population can support the growth and development of a country as long as certain requirements are met. Based on data from central bureau of statistics (BPS), Indonesia will face demographic bonus era during 2020 to 2035 period. Demographic bonus refers to a condition which is characterized by a large portion of people in the working age group compared to the non-working age groups in the age structure of nation's population, which represents a decline in the dependency ratio. Since there would be more adults who will be involved in productive activities than kids and the elderly (economic dependents), countries with more population in the working age brackets should enjoy higher level of per capita income due to higher economic production (Mason, 2005). In addition, three mechanisms transmit the effect of demographic bonus into economic growth, inter alia, change in labor supply, savings, and human capital (Bloom, et al., 2003)

The demographic bonus automatically alters the structure in the labor supply since more people of working age reflect an increase in the number of people looking for work. If the labor market can absorb more workers, then per capita production will rise. On the contrary, if the increase in the workforce ends up becoming unemployed, widespread instability will be the consequence, which in turn will lead to lower economic growth. Thus, demographic bonus must be accompanied by the creation of employment and labor market flexibility.

Meanwhile, demographic bonus also influences the level of saving in a country in a certain way. More employed people will have the disposition to save, which in turn contribute to higher investment and growth. To that end, in order to increase the level of saving from the future labor force, educational investment is required. Such investment will encourages a delay in the entrance of men and women into the workforce due to longer education, but once they start working, they will become even more productive. Educated workers enjoy higher wages and better standard of living thanks to higher acquired skills and competencies, which in turn translates into higher level of saving. Thus, policies that expand the opportunity to have access to education and health facilities will help the nation to take advantage of its demographic bonus (Hayes \& Setyonaluri, 2015).

However, Indonesian workforce still suffers from low productivity, low management skill, and insufficient ability to respond to international challenges and stiff competition, hence need to be prepared systematically through the use of human development and community programs (Effendi, 1996). Through the national budget, the Government of Indonesia is obliged by the Constitution to spend a minimum of 20 percent of its total annual expenditure on education. The compulsory expenditure is aimed at helping the poor have access to decent education, as well as enabling schools to improve education service provision through better facilities. Nevertheless, as a composite index of life expectancy, education (adult literacy and mean years of schooling), and per capita income indicators, Indonesia's Human Development Index (HDI) is still occupying the rank of 113 out of 188 countries, hence fell into the category of countries with medium human development in 2015. Such a rank put Indonesia below the rank of ASEAN countries, such as Singapore, Brunei, Malaysia, and Thailand.

Indonesia comprises five main islands, inter alia, Sumatera, Java, Kalimantan, Sulawesi, and Papua. Sumatera is located in the western part of Indonesia and covers an area of 473,481 square kilometers, making this island the second largest among Indonesian archipelago after Kalimantan. Bengkulu province in Sumatera, is an interesting object to study because it is renowned for being a students' city. Despite its fame, Bengkulu province is among the provinces in Indonesia that has spent less than 10 percent of its total annual budget on education over the last five consecutive years (2010 to 2014). In 
other words, the province spends less than a half of the mandated spending on education. The level of spending on education in Bengkulu is also reflected in the low rank the province has on HDI, which is $21^{\text {st }}$ among 33 provinces in Indonesia. With a score of 68.06 , Bengkulu province rank on HDI is below the national average.

To analyze the influence that human development has on capital formation in Bengkulu, this study does not only focus on, education expenditure, a factor that is the focus of this study, but also other factors, such as women empowerment, infrastructure, and health expenditure that have direct and indirect effect.

Based on the endogenous growth theory, expenditure on education and health is premised to contribute to human capital development (Lucas, 1988). Due to the return on education that includes higher individual earnings, among other factors, which are also associated with an increase in the number of schooling, and contribution to higher HDI, expenditure on education is generally considered productive expenditure. Higher HDI translates into higher competitiveness through higher value added that is ascribed to human capital (Tomas, 2011). Thus, efforts that encourage and promote human capital development through public spending in education are considered to contribute to accelerating economic growth as well. However, increase in public expenditure on education, which financed from taxes, has a crowding-out effect in the short run that is manifested in lower saving and investment in physical capital which may reduce labor supply (Annabi, et al., 2007). For instance, tax on labor income can be a disincentive against human capital development it influences the consumption-saving decision. On the contrary, increase in public spending on education is premised to increase the rate of human capital accumulation through better education quality in the long run. Likewise, spending on school facilities, by inducing improvement in school attendance, especially for poor students
(Angirst \& Lavy, 1999), also augments human capital development. Thus, spending on school infrastructure induces an increase in school enrollment rates and school attendance, and reduces health risks for school-age children (Lokhsin \& Yemtsov, 2005).

Meanwhile, spending on health also contributes to human capital formation through extending life expectancy, reducing illness, and increasing the competences of the workforce due to the availability of health services. Maitra \& Mukhopadhyay (2012) study finds that human capital can be transmitted to future generations, which increases the sustainability of human capital investment in the longer term (Maitra \& Mukhopadhyay, 2012). Thus, government expenditure on health has positive and significant influence on human development index, implying that health expenditures by inducing improvement in health indicators contribute to an increase in human capital stock (Razmi, et al., 2012). The availability of healthy people with longer life expectancy and higher motivation to learn promote human development.

In relation to women empowerment, demographic bonus means that more women are likely to enter the work force and support the family income. Thus, any policies which create conditions that motivate women to work increase the opportunity of an economy to take advantage of the demographic bonus. In this case, expanding capabilities afforded to women through education is one key element (Hayes \& Setyonaluri, 2015). Another finding explains that any factors that affect women empowerment, such as higher female literacy and high proportion of female enrolment at secondary level, contribute to human development as well (Nayak \& Mahanta, 2009). Increasing female education is expected to accelerate social development through lower fertility and mortality rates, better cognitive abilities to make family decisions, better nutrition for their children, greater involvement in political processes, and lower frequency of domestic violence (Neubauer, 2015). 
With regards to the influence that infrastructure has on human development, the fact that spending on infrastructure expands choices to improve incomes and lives of entire members of society, especially the poor ones, is premised to have positive influence on human development. It is generally argued that infrastructure contributes directly to improvement in conditions of life by enhancing labor productivity and providing favorable amenities for human existence. For example, transport and communication infrastructure is pivotal for people to access basic health services that are necessary for improving health conditions and life, especially for women and children. Basic infrastructure such as road connectivity to a school, facilities like separate toilets for boys and girls in the school are also critical determinants of the enrolment of girl children. Additional infrastructure is likely to change the lives of society to become more effective and also create indirect employment through new shops and services that emerge along the new roads.

A number of studies have shown the important role that infrastructure plays in human development. Electricity consumption per capita has positive and indirect impact on social development, particularly in countries with low and medium level of human development (Leung \& Meisen, 2005). In another study, investment in human capital achieved through improvements in infrastructure is found to enhance productivity (Otega, et al., 2015). Improving infrastructure has a significant influence on human development, with electricity playing the most important role in the case of Java as compared with other types of infrastructure such as clean water, roads, and the number of classrooms per student (Kustoharjo $\&$ Kim, 2011). The same study concluded that for every 1 percent increase in the proportion of households with electricity, induces an increase of HDI by 0.2 percent. However, the effect of changes in infrastructure on HDI takes some time. In the backdrop, it is evident that not a lot of previous studies focused on the relationship between infrastructure and human development at provincial level. In the focus that this research embarks on. This research, to the best of our knowledge is among the few that is trying to fill this gap. To that end, in addition to the main focus, of this research, this study also explored the relationship between the quality of infrastructure networks and human capital in Bengkulu.

\section{METHODS}

This study was conducted in Bengkulu Province that consists of nine districts and one city that include Southern Bengkulu, Central Bengkulu, Northern Bengkulu, Kaur, Kepahiang, Muko-muko, Rejang Lebong, Seluma, and Bengkulu city. The data set on government spending on education and and health were obtained from the Ministry of Finance, while data on Human Development Index (HDI), road infrastucture, and Gender Empowerment Measure were obtained from the central bureau of Statistics (BPS). This study covers all regencies in Bengkulu Province over the last five years, from 2010 to 2014 .

To analyze the impact of government spending on education on human development in Bengkulu, we used a dynamic panel data model specification that is reproduced below.

HDI $_{\text {it }}=\alpha+b_{1}$ edu_exp
$b_{3}$ women $_{\text {it }}+b_{4}+b_{2}$ health heastructure $_{\text {it }}+u_{i t}$

In equation (1), the dependent variable is HDI in district $i$ at time $t$. HDI is the measure of a composite statistic consisting of longevity (life expectancy at birth), knowledge (combination of adult literacy rate as weighted at two-thirds and mean years of schooling as weighted at one-third), and standard of living (per capita income), which represents quality of human resources. The independent variables include edu_exp it $_{\text {, }}$ or government spending on education which is the proportion of education expenditure to total regional expenditure budget as expressed in percent; health_exp ${ }_{i t}$, 
Nurfitriani and Romi Bhakti Hartarto - Does More Spending on Education Matter .....

Table 1. Chow Test

\begin{tabular}{lccc}
\hline \multicolumn{1}{c}{ Effects Test } & Statistic & d.f. & Prob. \\
\hline Cross-section F & 79,990 & $(9,36)$ & 0,000 \\
Cross-section Chi-square & 152,220 & 9 & 0,000 \\
\hline
\end{tabular}

Table 2. Hausman Test

\begin{tabular}{cccc}
\hline Test Summary & Chi-Sq. Statistic & Chi- S.q d.f & Prob. \\
\hline Cross- section random & 17,962 & 4 & 0,001 \\
\hline
\end{tabular}

Table 3. Estimation Result

\begin{tabular}{lr}
\hline Dependent Variable : HDI & \\
\hline Constant & $\mathbf{5 9 , 7 5 3 *}$ \\
Standar error & $(2,183)$ \\
edu_exp & $\mathbf{- 0 , 1 0 7 * * *}$ \\
Standar error & $(0,056)$ \\
health_exp & $\mathbf{- 0 , 0 9 5 *}$ \\
Standar error & $(0,033)$ \\
Women & $\mathbf{0 , 1 3 0 *}$ \\
Standar error & $(0,024)$ \\
Infrastructure & $\mathbf{0 , 0 2 7 *}$ \\
Standar error & $(0,007)$ \\
$\mathrm{R}^{2}=0.981$ & \\
F-Statistic $=143,407$ & \\
Prob(F-Stat) $=0,000$ & \\
\hline Significance: $* * * p<0.01 ; * * p<0.05 ; p<0.10$ &
\end{tabular}

or government spending on health which represents the proportion of health expenditure to total regional expenditure budget as expressed in percent; women ${ }_{\mathrm{it}}$, or gender empowerment measure, which represents the role of woman in the economy and politics as denoted in indices; and infrastructure ${ }_{\text {it, }}$ which represents the quality of government infrastucture in transportation, as measured by the proportion of road length in good condition to total road length (mileage). The unobserved regional specific effects and the mean-zero transitory shocks are captured by $u_{\mathrm{it}}$.

Prior to going further, we deemed in necessary to discuss ways to test which model was suitable to estimate our panel data set. To do that we used the Chow test to determine whether a fixed effect and common effect (random effect) model was the best specification for the dataset. If the Chow test results showed a rejection of the null hypothesis due to large probability values of the crosssection $\mathrm{F}$ and cross-section Chi-square, the fixed effects model would have been used as the appropriate model. Otherwise, common effect would be recommended as the better model specification.

Based on the table 1, there was strong evidence that the best model that explains the data is fixed effects. However, we still had to determine whether or not there were random effects in the using the Hausman test. If the probability value of the cross-section random was less the significance level of 1 percent, then we would reject the null hypothesis and use the random effects model instead. Hence, the best model will be fixed effect.

According to the table 2, we have strong evidence that no random effects were evident in the model. 


\section{FINDINGS AND DISCUSSION}

Table 3 presents the estimation results of the fixed effect model for the determinants of HDI.

The regression result shows the model fits the data well as shown by the value of $\mathrm{R}$-squared. The value of $\mathrm{R}$-squared is useful as it measures the ability of the model to explaining the variation in the dependent variable. The value of $\mathrm{R}$-squared lies between zero and one. The smaller the value the less variation of independent variables explains the variation of dependent variable. The value of determination that is close to one, is interpreted to mean that independent variables in the model explain almost all the information (variation) in the dependent variable. Based on regression output from fixed effect model, our R-squared value is 0.981 , which means that independent variables in the model explain $98.1 \%$ of variation in HDI, leaving only $1.89 \%$ variation in HDI unexplained in the model.

Based on our estimation, we report that government spending has little effect on HDI in Bengkulu province as it is only significant at 10 percent. According to previous research, many aspects affect the disparities in the fulfillment of education, such as poverty, natural disasters, war, social exclusion, and inappropriate public investment allocation (Sulistyastuti, 2007). The rationale behind this insignificant result is attributable to the fact that spending on education only focuses on school construction, while neglecting the quality of education and training for teachers. Since Bengkulu is a disaster-prone area, which is vulnerable to earthquakes, more spending on education through construction in school building only has little impact on human development. The lack of significance of our result may also be due to the suboptimal allocation in education spending which is still below the constitutionally mandated minimum of 20 percent during the observation period. In line with findings from another study, education sector spending is always lower than spending on other sectors in the regional governments budget (Syakdiah, 2005)
Corruption of local education authorities, such as the education bureau at the district level, has been partly explaining the insignificant role of education expenditure. For example, local governments in the province of Bengkulu procured books that were not recommended by the Ministry of National Education, and which could not be used by the time they reached the schools (Widoyoko, 2010). Moreover, up to IDR 11.7 trillion of teacher incentives for certification from 2008 to 2012 have been undisbursed and not received by teachers (ACDP, 2013). Even, many certified teachers have not received these benefits and those who have already received apparently did not receive the full amount since the fund has been stuck in the treasury of local autonomies.

Regression results showed that government spending on health has significant influence on human capital development, but its effect is negative. It implies that increasing the proportion of health expenditure to total expenditure by 1 percent, induces a decrease of 0.095 in HDI average, with other variables remaining constant. The negative relationship between government expenditure on health and HDI is probably due to the role of central government in financing health expenses which makes the district governments depend heavily on the central government with limited financial capacity (Yefriza, 2014). Therefore, it will be uneasy for them to perform their functions in the health sector due to reduced or insufficient public health spending in the central budget. Besides, lack of institutional arrangement, such as the absence of political engagement and policy clarity along with low levels of transparency and accountability, to comply with public expenditure management has weakened the role of district governments to intervene the health sector which results in misallocation and inefficient size of public health spending. This situation has led to the delays in budget approvals. As a consequence, there is no substantial improvement in health at all.

Local government spending on health in Bengkulu is not optimal with respect to 
the training of health workers, rather in the construction and development of hospitals. Moreover, some health funds are expended on purchasing medical equipment and in the construction of health centers, which have indirect impact on the community. In addition, there are many cases of corruption, collusion, and nepotism in the health sector maybe to blame for the negative relationship between health spending and HDI. The Indonesia Forum for Budget Transparency in 2014 disclosed that Bengkulu province is ranks No. 10 corrupt cases (257 cases). A number of corruption cases that involve misappropriation of the local government hospital fund by the governor and regional budget for health equipment purchase by the public health office, may also contribute to the inverse relationship between government spending on health and HDI.

Nonetheless, our finding in this study also found that Gender Empowerment has a positive significant influence on HDI in Bengkulu province. An increase in the Gender Empowerment Index by one point, while holding other variables constant, induces an increase in HDI by 0.13 point on average. The role of women's participation in improving HDI is reflected in the increase in the number of legislative candidates, leaders, and professional women in Bengkulu Province, which in turn has contributed to higher HDI in Bengkulu Province over the last five years.

The regression result also showed that the quality of road infrastructure has positive and significant influence on human capital formation in Bengkulu. Thus, any effort to improve on the condition of road infrastructure quality by 1 percent while holding other variables constant, induces an increase in the Human Development Index by 0.027 point on average. This finding is in line with previous research that also showed infrastructure as playing an important role in human capital development (Sapkota, 2015). Better quality of road infrastructure means easier access for the community to education and health facilities that the government provide. Better accessibility that is an outcome of improvement in road conditions in the regions in Bengkulu province stimulates more public involvement in economic activities, and in turn an increase in societal welfare. As a consequence, people earn more income, which enables them to have decent education and health services.

\section{CONCLUSION}

The main purpose of this study is to determine the influence that government expenditure on education has on human capital formation in Bengkulu Province. The research used panel data on nine districts and one city in Bengkulu Province for the 2010 to 2014 period. Results showed that government spending on education has little effect on HDI as it is only significant at 10 percent level of significance. Government spending on health has significant impact on human development, but the impact is negative. What makes the relationship between government expenditure in health and HDI negative is probably due to misallocation of health funds. Gender Empowerment Measure has significant and positive impact on HDI in Bengkulu province. The role of women's participation toward the improvement of HDI is reflected in among others an upward trend in the number of legislative candidates, leaders, and professional women in Bengkulu Province over the last five years. The regression result also demonstrates that the quality of road infrastructure has positive and significant effect on human capital formation in Bengkulu.

The effect of government spending on education is very small. This insignificance may be attributable to focus of the spending itself. Local government spending on education only focuses on the physical construction of school facilities, which do not have direct impact on human capital formation. To that end, unlike previous studies on that found a positive relationship between government spending on education, health and HDI, this research showed a negative relationship. Spending on health services in Bengkulu does not target 
the training of health workers such as doctors, midwives, nurses, or surgeons, rather is mainly tailored toward the physical construction and development of hospitals. In addition, some health funds are spent on purchasing medical equipment and construction of health centers, which do not as much impact on the community. In addition, many cases of corruption, collusion, and nepotism in health sector also undermine the influence that government spending on health has on HDI.

Thus, as Indonesia prepares to face the demographic bonus, Bengkulu local government must play an increasingly important role in improving the quality of human capital. The government should allocate its budget based on the dictates of the constitution, which sets a minimum of 20 percent. Equally important is the need for the local government to prevent and control rampant corruption, collusion, and nepotism.

The study also found that there is need for more attention from the government toward improving infrastructure and women empowerment. Better quality of road infrastructure and increased access for the women to public facilities and political process, will accelerate human development. In addition, government should also increase expenditure on infrastructure and woman empowerment programs.

Demographic bonus with quality infrastructure should motivate people to undertake economic and productive activities, which can contribute to economic growth. Expenditure on women empowerment facilities and programs will help to reduce the dependency ratio in future and in turn contribute to informed family decision making on nutrition and education. Since knowledgeable women are more aware of health issues, spending on women empowerment should change their attitude favor of having few children in their families due to their participation in the workforce and political process. Smaller family size will make it possible for families to invest more each the education and health of every child leading to quality educated, and health children in future. Highly education workforce in future will be more productive and earn higher wages and better living standards compared to their parents.

Furthermore, during the regional autonomy era, there is need for local governments to increase their fiscal capacity through involving the private sector in infrastructure development and embark on and strengthen programs that increase domestic savings. This effort will lead to balanced, equitable, and sustainable growth in the future.

\section{REFERENCES}

ACDP, I. (2013, November 26). Up to IDR 11.7 Trillion Undisbursed Teacher Incntive. Retrieved 25 February, 2018, from https:/acdpindonesia.wordpress.com/ category/financingbudgeting/page/46/?i frame $=$ true $\&$ preview $=$ true $\% 2$ Ffeed $\% 2 F$

Angirst, J., \& Lavy, V. (1999). Using Maimonides' rule to estimate the effect of class size on scholastic achievement. Quarterly journal of economics, 114(2), 533-575.

Annabi, N., Harvey, S., \& Lan, Y. (2011). Public expenditures on education, human capital and growth in Canada: an OLG model analysis. Journal of Policy Modeling, 33(6), 852-865.

Bloom, David, E., David, C., \& Jaypee, S. (2003). The Demographic Dividend: A new Perspective on the Economic Consequences of Population. Santa Monica: RAND.

Effendi, S. (1996). Meningkatkan Kemampuan Kelembagaan Untuk Mendukung Pembangunan Kualitas Manusia: Suatu Perspektif Administrasi Negara. Jurnal Kebijakan Administrasi Publik, 1(1), 29-43.

Hayes, A., \& Setyonaluri. (2015). Taking Advantage of the Demographic Dividend in Indonesia: A Brief Introduction to Theory 
and Practice. Jakarta: UNFPA Indonesia.

Kustoharjo, H., \& Kim, D. (2011). Infastructure and human development: The case of Java, Indonesia. Journal of the Asia Pacific Economy, 16(1), 111-124.

Leung, C., \& Meisen, P. (2005). How electricity consumption affects social and economic developmentby comparing low, medium and high human development countries. Retrieved February 25, 2018, from https://www.geni.org/globalenergy/ issues/global/qualityoflife/HDI-vs-Electricity-Consumption-2005-07-18.pdf

Lokhsin, M., \& Yemtsov, R. (2005). Has Rural Infrastructure Rehabilitation in Georgia Helped the Poor? The Wold Bank Economic Reviw, 19(2), 311-333.

Lucas, R. (1988). On the Mechanics od Economic Development. Journal of Monetary Economics, 22, 3-42.

Maitra, B., \& Mukhopadhyay. (2013). Public Spending on Education, Health Care and Economic Growth in Selected Countries of Asia and the Pacific. Asia-Pacific Development Journal, 19(2), 19-48.

Mason, A. (2005). Demographic transitions and demographic dividens in developed and developing countries. Proceedings of the United Nations Expert Group Meeting on Social and Economic Implications of Changing Population Age Structures, 81-101.

Nayak, P., \& Mahanta, B. (2009). Women Empowerment in Assam. PCC JOurnal of Economics and Commerce, 6(6), 61-74.

Otega, O., Salleh, D., \& Din, B. (2015). Infrastructure and Human Development in Nigeria: A Study of the South-South Geo Political Zone. IOSR Journal of Humanities and Social Science, 20(9), 65-73.

Razmi, M., Abbasian, E., \& Mohammadi, S. (2012). Investigating the Effect of Government Health Expenditure on HDI in Iran. Journal of Knowledge Management, Economics, and Information Technology, 2(5), 1-8.
Sapkota, J. B. (2014). Infrastructure Access and Human Development: Cross-Country Evidence and Post-2015 Development Strategies. Argentina: FLACSO-ISA Joint International Conference Global and Regional Powers in a Changing World.

Sulistyastuti, D. R. (2007). Pengarusutamaan MDGs dalam pembangunan Kualitas Manusia. Jurnal Kebijakan dan Administrasi Publik, 11(2), 159-186.

Syakdiah. (2005). Pendanaan Pendidikan di Indonesia. Jurnal Kebijakan dan Administrasi Publik, 9(2), 109-122.

Tomas, V. (2011). National Competitiveness and Expenditure on. Journal of Competitiveness(2), 3-10.

Widoyoko, J. (2011). The Education Sector: The fragmentation and adaptability of corruption. In The State and Illegality in Indonesia (p. 165). Leiden: KITLV Press.

Yefriza. (2015). Managing Public Health Expenditure in Indonesia. Bulletin of Indonesian Economic Studies, 51, 147-149. 